$\begin{array}{ll} & \text { Etnográfica } \\ \text { etnográfica } & \text { Revista do Centro em Rede de Investigação em }\end{array}$

Antropologia

vol. 14 (1) | 2010

Vol. $14(1)$

\title{
Ethnography and the public sphere: summarizing questions
}

Etnografia e esfera pública: questões em sumário

\section{Manuela Ivone Cunha e Antónia Lima}

\section{(2) OpenEdition}

Journals

Edição electrónica

URL: https://journals.openedition.org/etnografica/158

DOI: 10.4000/etnografica. 158

ISSN: 2182-2891

\section{Editora}

Centro em Rede de Investigação em Antropologia

\section{Edição impressa}

Data de publição: 1 fevereiro 2010

Paginação: 61-69

ISSN: 0873-6561

\section{Refêrencia eletrónica}

Manuela Ivone Cunha e Antónia Lima, «Ethnography and the public sphere: summarizing questions», Etnográfica [Online], vol. 14 (1) | 2010, posto online no dia 21 outubro 2011, consultado o 11 fevereiro 2022. URL: http://journals.openedition.org/etnografica/158 ; DOI: https://doi.org/10.4000/etnografica. 158 \section{License.}

Etnográfica is licensed under a Creative Commons Attribution-NonCommercial 4.0 International 


\title{
Ethnography and the public sphere: summarizing questions
}

\section{Manuela Ivone Cunha and Antónia Lima}

\begin{abstract}
In line with the conference "Ethnografeast III: Ethnography and the Public Sphere", from which it stems, this dossier aims at equating uses and products of ethnography as they relate with each other within the context of the public sphere. Keeping the conference's commitment to interdisciplinarity, pluralism in genres and theoretical suasions, it focuses on the way political and civic uses of ethnography enter into the conceptual elaboration of its products, and, conversely, on how the design and implementation of ethnographic research may contribute to enhance public debate.
\end{abstract}

KEYWORDS: ethnography, public sphere, social issues, relevant research, uses of ethnography.

THE GROUP OF ARTICLES THAT COMPOSE THIS DOSSIER IS ONE OF THE outcomes of the third edition of the conference "Ethnografeast", held in Lisbon in June 2007. ${ }^{1}$ In line with the previous editions of the conference, it aimed at reflecting on the practice - as well as on the promises and on the achievements - of ethnography as a distinctive mode of inquiry and potential form of public consciousness (Wacquant 2003). More specifically, it was now aimed at equating uses and productions of ethnography as they relate with each other within the context of the public sphere. The way political and civic uses of ethnography shape the conceptual elaboration of its products, and, conversely, how the design of ethnographic research enables it to shape

l A joint organization by the Centro de Estudos de Antropologia Social (CEAS, Portugal) and the journal Ethnography, it was coordinated by Manuela Ivone Cunha (CRIA/UM), Antónia P. Lima (CRIA/ISCTE) and Loïc Wacquant (University of California, Berkeley/Centre de Sociologie Européenne) and sponsored by the Wenner-Gren Foundation for Anthropological Research, CEAS, Instituto Superior de Ciências do Trabalho e da Empresa (ISCTE), Fundação para a Ciência e a Tecnologia (FCT), Fundação Luso-Americana (FLAD) and Fundação Calouste Gulbenkian (FCG). 
or participate in public debate, motivated a number of questions deserving a continuing debate. These may be summarized as follows.

\section{WHAT COUNTS TODAY AS ETHNOGRAPHY?}

The recent expansion of ethnographic methods into other disciplines, their proliferation from literature to political science to business, has made the reflection on current ethnographic approaches by anthropology and sociology, the founding disciplines of ethnography, all the more critical. Furthermore, cultural discourses on society and politics multiply. Social research is now enmeshed in a social reality that includes many public voices. It is nearly impossible today to conceive of social research that would be cut off from the public sphere. The former is inevitably impacted by the latter, if only because the realities it studies are not deaf to the rumor of what goes on in the public arena and often have a voice in it. More important, every public voice is a potential expert - not to mention that everyone may claim to be a "knower" of a contemporary topic based on their own personal experiences, which are summoned as knowledge. Under the light of these multiplying "expertises", as well as given the unprecedented dissemination of the "ethnography" label well beyond its original disciplinary niche, ethnography may face the risk of diluting itself as one more specialized commentary of cultural critique, among others. Where does ethnography stand vis-à-vis other qualitative methodologies and cultural discourses on society and politics? Is there something to be gained by revisiting with contemporary eyes classical criteria for the craft of field inquiry, such as close-up, on-the-ground observation of people and institutions, or the researcher embeddedness in the (not necessarily "local") social networks, milieus of acquaintance, or social scenes (see Beaud and Weber 2003; Weber 2009)? The issue of what counts today as ethnography involves thus in the present context aspects other than the sometimes debated issues of scale - how big can the proper ethnographic scale be? - or "locality" (Bromberger 1987).

An ongoing discussion clarifying and fortifying the parameters of the production, circulation, and consumption of ethnography as a specific intellectual product seems therefore even more necessary in the present juncture. ${ }^{2}$ This discussion was informed by the spirit presiding "Ethnografeast" of fostering a dialogue i) between sociology and anthropology, which have created and defined ethnography's standards; ii) between "national" scholarly traditions; and iii) between different styles of ethnographic work (Wacquant 2003).

2 These issues were specifically addressed in "Ethnografeast II: The Making of Ethnography" (held in 2004 at the École Normale Supérieure, Paris), which focused on ethnography's different stages of production. 


\section{ETHNOGRAPHY AND THE PUBLIC SPHERE}

The third edition of the conference brought together a new group of field-based anthropologists and sociologists who developed the reflections launched in the previous meetings and centered them on the relationship between ethnography and the public sphere. Questions raised by this relationship go beyond classical discussions about "applied-research", 3 "outcome-oriented research", "research-action" or other research whose "usefulness" is understood strictly in instrumental terms. They involve not only research which engages policymaking and makers, but, more widely, research that tackles salient social issues or politically significant phenomena in ways that challenge common notions and institutions. ${ }^{4}$ Examples of such issues are immigration, urban poverty, incarceration, health care, the transformation of welfare policies, new genetic technologies, new forms of family and "relatedness", the politics of culture and cultural heritage - among many others today. ${ }^{5}$

The relevance of ethnographic research for civic concerns or the public framing of research questions and findings, the fit or lack of fit between public agendas and research agendas, the problems and opportunities entailed by their intersection, the audiences and the circulation of ethnographic products, the negotiation of ethnographic expertise, the question of the continuities and discontinuities between ethnographic knowledge and civic choices or political decisions, for example, are some of the issues that call for a broad reflection on the effects of public debates on ethnography and vice-versa.

In short, how do the political and civic uses of ethnography enter into the conceptual elaboration of ethnographic productions, and conversely, how does the design and implementation of ethnographic research enable it to impact (or not) public debate?

The relationship between ethnography and the public sphere thus requires a broad discussion not only about the effects of ethnography on public debates, but also about the effects of public debates on ethnography.

Such a reflection also has to take into account both the role of theory in calibrating socially relevant ethnography and the broader relationship between academic research and the public realm. As far as the social sciences are concerned, such a relationship varies along different countries, and this requires comparative attention. But issues of ethnographic diversity in academic space cannot not be ignored either. Keeping in mind the threefold commitment to

3 For an overview see for example Sillitoe (2006).

4 See Burawoy (2009) for an incisive overall reflection.

5 In a recent overview, Melissa Checker (2009) summarizes some of the main themes and trends of the year 2008 where anthropological work travelled outside the academia and informed in several ways public discourse in the United States: war and peace, climate change, natural, industrial, and development induced disaster recovery, health disparities, human rights, among other topical areas. 
internationality, interdisciplinarity, and pluralism in genres and theoretical suasions which defines this biennial meeting of ethnographers since its inception, such dimensions also reflect themselves specifically on the design and production of ethnographic research. Do different genres (e.g. theory-driven versus narrative-driven ethnographies), representational norms and devices (e.g. theoreticist versus praxeological ways of integrating theory in ethnographic texts; in other words, theory as a text itself, separated from the empirical object at hand, versus a tight linkage between theoretical analyses and ethnographic data in every step; see Willis and Trondman 2002), academic conventions, "national" traditions, and "sociological" or "anthropological" formats of ethnography impact on ethnographers' scholarly dialogue? How do the different strands of ethnography across genres and disciplines treat - and react to - public demands and civic issues?

\section{CATEGORIES, RESEARCH QUESTIONS, AGENDAS}

Questions about the pas de deux between ethnography and the public sphere as Sylvie Fainzang nicely puts it in her article - divide into several others. They can be organized under the sequence before-after the ethnographic inquiry, in spite of its artificiality in ethnographic practice.

First, how is the choice of a research topic constructed in the midst of the pressures and demands of the public sphere? Prior to the inquiry, there is the risk of following too close on the footsteps of public debates, and of adopting the issues, problems, and categories as they stand pre-construed in the public arena (e.g. "the street", "urban violence", culturally specific categories of "race", the "individual", etc.). ${ }^{6}$ Empirically-grounded research is not the same as empiricism. Theory and epistemic reflexivity are especially needed in this case, in order to avoid the pitfalls of false or misconstrued topics (Bourdieu 1997; Bourdieu and Wacquant 1992; Cefaï and Amiraux 2002). Also, even if the research focus fits the frame of a "social problem", it doesn't follow from here that it should be designed as a diagnosis from the outset (see Cunha 1991 for an analysis of this issue; Cunha 2008).

Ethnographic knowledge can however be developed in a fruitful engagement with the public sphere. First, public debates may actively contribute to the critical rethinking of "scientific" categories and the renewal of theoretical questions. To give an example, debates around gay access to marriage or adoption have contributed to further deconstruct aspects of the notion of "family" and to the overall aggiornamento of such category within the social sciences and the humanities (Fassin 2001; Almeida 2009). The political import of

6 See in this respect, for example, Wacquant (2002), Bourdieu and Wacquant (1999), Delgado (2003). 
this kind of category deconstruction or of the denaturalization of social and historical phenomena is well acknowledged in the social sciences. But the same potentially happens the other way around, that is, politicization may stimulate similar types of critical denaturalization. Other creative tensions between the couplet ethnography-public sphere can be invoked, such as the ones involving strategic uses of the categories of culture, identity, and difference in the empowerment of subaltern groups, analyzed elsewhere by Miguel Vale de Almeida (2007a).

Second, whereas public agendas can be imported to - or imposed on ethnographic research, ethnography can, conversely, draw attention to silent, unnamed problems that are yet unrecognized as social issues in the public realm (see for example Hondagneu-Sotelo 2007 [2001] for the return of paid domestic work in the United States).

\section{THE CIRCULATION OF ETHNOGRAPHIC KNOWLEDGE}

Other questions are related to the aftermath of the inquiry. How does ethnographic knowledge circulate and how does it reach the public sphere? How to navigate publics and reach audiences outside the academe? This raises beforehand the issue of the public representation of research legitimacy and, more specifically, the perceived authority of qualitative versus quantitative research. In other words, what are the public perceptions of the "scientificity" of qualitative findings? Ethnographers face the challenge of communicating unquantifiable findings in a public sphere more used to polls and simple statistics that seem to have the imprimatur of "hard" science. ${ }^{7}$ Also, how to answer the "how many?" question when an ethnography deals with hidden populations or with universes whose parameters are unknown? This may stand as an obstacle to media receptiveness and in the negotiation of ethnographic expertise - in addition to other difficulties in managing media expectations, such as the stress on the routine rather than on the exceptional, different writing conventions and styles of presentation, among others. On the other hand, however, the attempt to reach and communicate with wider audiences may stimulate the experimentation of new ethnographic forms (e.g. Hondagneu-Sotelo 2004 for the use of theater; Almeida 2007b for the use of blogs).

The group of "Ethnografeast" articles in this dossier provide specific illustrations of relevant ethnographic research on contemporary social issues. They

7 Blastland and Dilnot (2009) provide a humorous but rigorous account about the impact of statistics in public life, about the over-expectations and the aura of "truth" that surround numbers, as well as about media and public (mis)readings of statistics. Along with other, less anecdotal examples, it is possible to conclude that most people have more than the average number of feet. Because of amputations, birth defects and the like, the average number of feet per person across the human population is slightly fewer than two. 
adopt a ground-level view, favoring direct observation of concrete practices and discursive interactions that can highlight both detailed processes of daily life and structural aspects that statistics alone are unable to capture.

Dealing with notions of "deviance" - criminal or psychiatric - Isabelle Coutant and Chiara Pussetti address encounters within "normalizing" institutions that put at play different systems of meaning and the structural, cultural, and historical conditions that lie behind the tension between such systems. Acknowledging the growing intervention of state institutions in the regulation of "troubled youth" - "endangered youth" or youngsters with problems with the law -, Isabelle Coutant focuses on the dynamics of trainers-trainees in a juvenile institution, on how the moral authority of the former is established, and on the way an institution impacts on the processes of personal conversion from a street ethos into "settling down" and "play the game".

As to Chiara Pussetti, she addresses the intervention of psychiatric institutions in the regulation of immigrant's experiences of suffering, and especially the pathologization of "difference" that this regulation conveys. Focusing on the colonial legacies that shape the diagnosis, treatment, and, more generally, the frameworks for interpreting interaction within a mental health setting for migrants, she draws attention to the misunderstandings surrounding clinical encounters between care providers and care recipients embedded in different histories, discourses, and cultural frames of reference.

Sylvie Fainzang and Susana Viegas provide two rich examples on different ways of critically incorporating public debates and political issues into ethnographic research. Moreover, they also illustrate different possibilities - different because context-specific and therefore requiring views and approaches adapted to such specificity - of mutual constitution and of productive communication between ethnographic research and the public sphere.

Sylvie Fainzang's ethnography echoes the public debate on patient's information and takes it into account, but the research proceeds by re-elaborating the terms of that debate in accordance to what fieldwork and observation reveal, and by adopting a wider, complexified perspective. By "re-questioning the questions" that circulate in the public sphere in the first place, it is able to feed back into the public debate and to re-orient it in ways more attuned to the social realities that it involves - namely by drawing attention to the social mechanisms that structure doctor-patients communication and the flow of information between them.

It is also by adopting a wider, comparative, and therefore complexified perspective that Susana Viegas deals with demands stemming from the public arena. Her case is not so much about the necessity of stepping out of a problem's public framework in order to empirically assess the very terms in which it can be formulated - and of contributing to move forward public debate in that way. Rather, it is about the ability to mediate conflicting public agendas. 
Not by seeking a common denominator to which they can both be reduced, but by making them compatible through situated ethnographic knowledge. These are conflicts pertaining to the identification of "indigenous land" and to the negotiation of the local, variable limits of such category. As it stands, the category of "indigenous land" is pre-defined in the public agenda (and in the Brazilian Constitution, to begin with), but it is not without presenting a reflexive ingredient itself as it echoes both indigenous and anthropological debates already.

\section{OLD QUESTIONS: A REMINDER}

A last - or, in logic, perhaps previous - question remains here unaddressed, but runs parallel to this issue. Briefly, up to what point ethnography and the public sphere, as domains of action and discourse, should be made continuous to each other? What are the nature and the limits of their relative autonomy? This, in fact, is a twofold, double-edged question. First, what leeway does the aim of social relevance leave for ethnography in general? Ethnographic research, even when question-driven, tends to adopt broad focuses and diffuse approaches which do not fit easily into narrowly defined issues. Is there some room left for irrelevance - even in order to be relevant in unanticipated ways?

Second, and conversely, up to what point should civic choices and political decisions be made in the name of ethnographic knowledge - or any "scientific" discourse, for that matter? Should that knowledge be the ultimate referee in civic struggles and political debates? ${ }^{8}$ Old questions return and remain open.

8 See Cunha (2007) for a cautionary remark concerning the limits, in terms of civic relevance, of the social sciences' deconstruction of natural differences as the basis for social inequalities (sex/gender, "racial" differences). 


\section{REFERENCES}

ALMEIDA, Miguel Vale de, 2007a, "On difference and inequality: the lessons of ethnographic experience”, in António Pinto Ribeiro (ed.), The Urgency of Theory. Manchester, Carcanet and Fundação Calouste Gulbenkian, 44-78.

— $2007 \mathrm{~b}$, "Webbing ring: on fieldwork blogging, ethnography, and the public sphere", paper presented at "Ethnografeast III: Ethnography and the Public Sphere", Lisbon.

— — 2009, A Chave do Armário: Homossexualidade, Casamento, Família. Lisbon, Imprensa de Ciências Sociais.

BEAUD, Stéphane, and Florence WEBER, 2003, Guide de l'enquête de terrain. Paris, La Découverte.

BLASTLAND, Michael, and Andrew DILNOT, 2009, The Numbers Game: The Commonsense Guide to Understanding Numbers in the News, in Politics and in Life. New York, Gotham Books.

BOURDieU, Pierre, 1997, Méditations pascaliennes. Paris, Les Éditions du Seuil.

BOURDIEU, Pierre, and Loïc WACQUANT, 1992, An Invitation to Reflexive Sociology. Chicago, University of Chicago Press.

— 1 1999, "On the cunning of imperialist reason", Theory, Culture and Society, 16 (1): 41-58. BROMBERGER, Christian, 1987, "Du grand au petit: variations des échelles et des objets d'analyse dans l'histoire récente de l'ethnologie de la France”, in I. Chiva and U. Jeggle (eds.), Ethnologies en miroir. Paris, Éditions de la Maison des Sciences de l'Homme: 67-94.

BURAWOY, Michael, 2009, "Epilogue: on public ethnography”, in M. Burawoy, The Extended Case Method: Four Countries, Four Decades, Four Great Transformations, One Theory. Berkeley, University of California Press, 267-278.

CEFAÏ, Daniel, and Valérie AMIRAUX, 2002, "Les risques du métier: engagements problématiques en sciences sociales”, Cultures et Conflits, 47 (3): 15-48.

CHECKER, Melissa, 2009, "Anthropology and the public sphere, 2008: emerging trends and significant impacts", American Anthropologist, 111 (2): 162-169.

CUNHA, Manuela P. da, 1991, “Investigar 'problemas sociais': equívocos e dilemas de uma etnografia na prisão”, Cadernos do Noroeste, 4 (6-7): 193-209.

— Devillard (eds.), Diccionario de Relaciones Interculturales: Diversidad y Globalización. Madrid, Editorial Complutense, 67-71.

— 2008 , "Closed circuits: kinship, neighborhood and imprisonment in urban Portugal", Ethnography, 9 (3): 325-350.

DELGADO, Manuel, 2003, "Del movimiento a la mobilización: espacio, ritual y conflicto en contextos urbanos”, in J. Freitas Branco and A.I. Afonso (eds.), Retóricas sem Fronteiras, 2. Oeiras, Celta, 143-165.

FASSIN, Eric, 2001, "Same sex, different politics: 'gay marriage' debates in France and the United States", Public Culture, 13 (2): 215-232.

HONDAGNEU-SOTELO, Pierrette, 2004, "Making ethnographies public", paper presented at "Ethnografeast II: The Making of Ethnography”, École Normale Supérieure, Paris.

— 2007 [2001], Domestica: Immigrant Workers Cleaning and Caring in the Shadows of Affluence. Berkeley and Los Angeles, University of California Press. 
SILLITOE, Paul, 2006, "The search for relevance: a brief history of applied anthropology", History and Anthropology, 17 (1): 1-19.

WACQUANT, Loïc, 2002, "Scrutinizing the street: poverty, morality, and the pitfalls of urban ethnography”, American Journal of Sociology, 107 (6): 1468-1532.

—, 2003. "Ethnografeast: a progress report on the practice and promise of ethnography", Ethnography, 4 (1): 5-14.

WEBER, Florence, 2009, Manuel de l'ethnographe. Paris, Presses Universitaires de France.

WILLIS, Paul, and Mats TRONDMAN, 2002, "Manifesto for ethnography”, Ethnography, 1 (1): 5-16.

Etnografia e esfera pública: questões em sumário • Manuela Ivone Cunha • CRIA/UM, Portugal • micunha@ics.uminho.pt • Antónia Lima • CRIA/ISCTE, Portugal • antonia.lima@ iscte.pt

Em linha com a conferência "Ethnografeast III: Etnografia e Esfera Pública”, na qual teve origem, este dossiê visa equacionar os usos e os produtos da etnografia e o modo como se articulam entre si na esfera pública. Mantendo os princípios de interdisciplinaridade, de pluralismo nos géneros e nas filiações teóricas que marcaram a conferência, pretende focar a maneira como os usos cívicos e políticos da etnografia podem tomar parte na elaboração conceptual das suas produções e, conversamente, no modo como o desenho e a realização da investigação etnográfica podem contribuir para a qualidade do debate público.

PALAVRAS-CHAVE: etnografia, esfera pública, questões sociais, investigação relevante, usos da etnografia. 